\title{
Biodegradation of volatile CFCs, H-CFCs and VC in compost and marl
}

The biodegradation of volatile fully chlorofluorinated hydrocarbons (CFCs), partly chlorofluorinated hydrocarbons ( $\mathrm{H}$ CFCs) and vinyl chloride (VC) were investigated in compost and marl in laboratory studies. Trichlorofluoromethane (R11), dichlorodifluoromethane (R12), 1,1,2-trichlorotrifluoroethane (R113), difluoromethane (R32) and VC were biodegradable in compost under anaerobic conditions, probably by methanogenic bacteria. The anaerobic decomposition products of R11 were dichlorofluoromethane (R21) and chlorofluoromethane (R31). The degradation product of $R 12$ was chlorodifluoromethane (R22). R11 and its degradation products have the inhibiting effects of the R12 degradation under anaerobic conditions. The partly halogenated hydrocarbon R22 and VC were degraded preferentially under aerobic conditions in marl, probably by methanotrophic bacteria. Under aerobic conditions R22 and VC have inhibited the biodegradation of methane by methanotrophic bacteria.

\section{Introduction}

During the last few decades, many products manufactured in Germany used volatile chlorofluorocarbons (CFCs) and volatile chlorocarbons (VCCs). These products ended up, in relatively large quantities, in the landfills mixed with municipal solid waste (MSW) as well as with commercial and industrial wastes. These substances can be transported from the landfill into the environment in both the gaseous and liquid phases. Analyses of landfill gas (LFG) have proven that the compositions of trace substances change with time (Deipser \& Stegmann, 1994; Deipser et al. 1996). It has, therefore, been suggested that the trace substances are microbiologically degradable (Deipser \& Stegmann 1997a).

A number of biological degradation processes take place in conventional (reactor) landfills due to the concentration of organic matter and to the amount of moisture in the landfills. These are mainly anaerobic degradation processes, which usually lead to the decomposition of organic sub-

\begin{abstract}
Anna Deipser
Department of Waste Management, Technical University of Hamburg-Harburg, Schwetzingen, Germany

Keywords - CFCs, H-CFCs, trichlorofluoromethane, R11, dichlorofluoromethane, R21, chlorofluoromethane, R31, difluoromethane, R32, chlorodifluoromethane, R22, vinyl chloride, VC, trichlorotrifluoroethane, R113, anaerobic and aerobic biodegradation, compost, marl, landfill, landfill gas, LFG, cometabolism, inhibition competitive inhibition, methanogenic bacteria, methanotrophic bacteria
\end{abstract}

\begin{abstract}
Corresponding author: Anna Deipser, Dipl.-Ing., Technical University of Hamburg-Harburg, Department of Waste Management, Helmholtzstraße 27, 68723 Schwetzingen, Germany
\end{abstract}

Received 23 September 1996, accepted in revised form 7 April 1998 stances into primarily methane and carbon dioxide. Aerobic conditions may be found along the surface of the landfills, due to a higher supply of oxygen.

VCCs and CFCs are of significance due to their toxicological or environmentally damaging effects. It is, therefore, of interest to know if these compounds are biologically degradable under different milieu conditions (Christensen et al. 1994) and what the resulting decomposition products would be. The most quantitatively important CFCs (trichlorofluoromethane (R11), dichlorodifluoromethane (R12) and 1,1,2-trichlorotrifluoroethane (R113) (Deipser \& Poller 1990; Deipser \& Stegmann 1993, 1994)) and vinyl chloride (VC) as degradation product were chosen for this investigations, including the partly chlorofluorinated hydrocarbons (H-CFCs) dichlorofluoromethane (R21), chlorofluoromethane (R31), chlorodifluoromethane (R22), difluoromethane (R32) and fluoromethane (R41) which may occur as decomposition products and may, in some cases, be utilized as refrigerants in cooling units and as solvents like the CFCs. 
Table 1. Compounds used in the experiment and their observed degradation products.

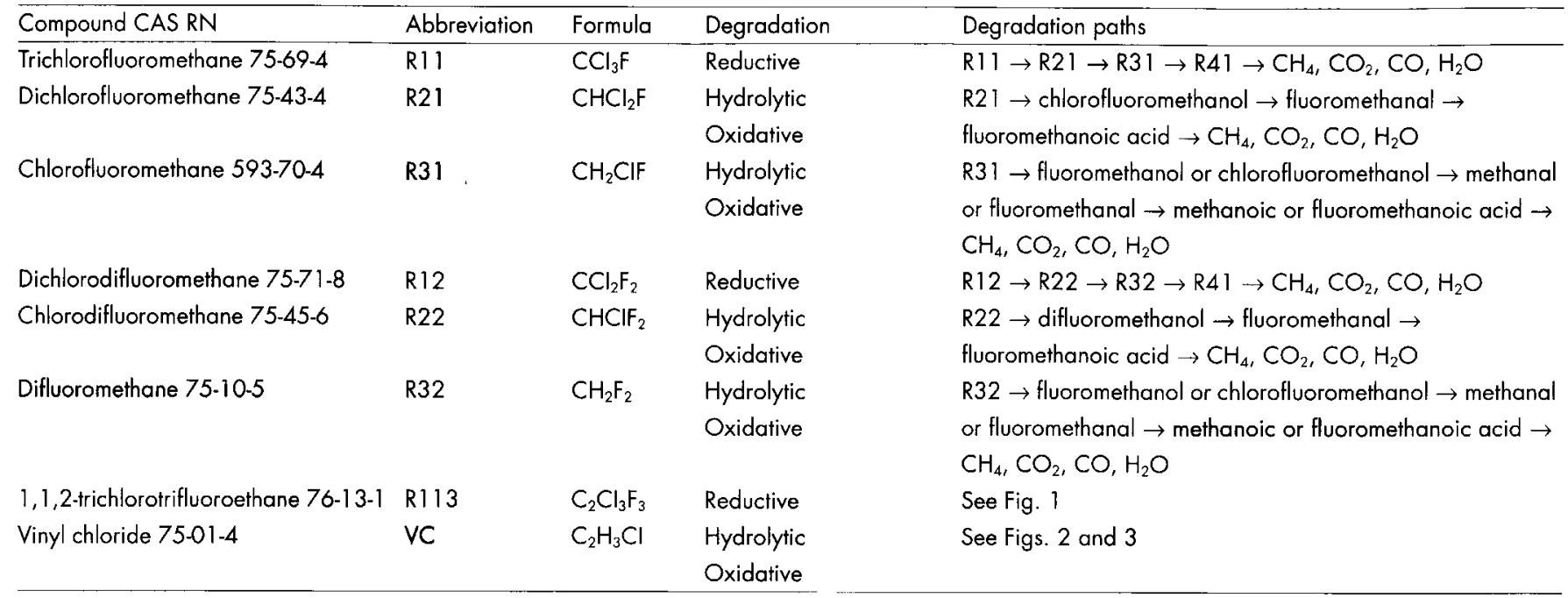

\section{Anaerobic and aerobic biodegradation of CFCs, H-CFCs and VC}

The compounds that were evaluated have damaging effects to the environment and to the human health. CFCs and $\mathrm{H}$ CFCs are depleting the stratospheric ozone layer as a result of chemical reactions involving the chlorine atoms they contain. Therefore, they have a high global warming potential (GWP). In addition, VC and R31 are gases known to be carcinogenic. It could be assumed that reductive biodegradation of these substances can occur by replacement of chlorine and fluorine atoms by hydrogen, probably in cometabolism with similar biodegradation processes induced from methanogenic bacteria.

The decomposition products from R11, R12, R113 and $\mathrm{R} 32$, which may theoretically form after reductive dechlorination and perhaps even defluorination, are given in Table 1 and in Fig. 1.

Although carbon monoxide, carbon dioxide and water are set free as end products, they can also form via intermediate products which are not mentioned in this article (Krone et al. 1991; Lesage et al. 1992). In the presence of an electron donor atom it is likely that methane, ethane or ethene form as decomposition products (e.g. Fathepure \& Boyd 1988; Bouwer \& McCarty 1983; Vogel et al. 1987).

Under aerobic and anaerobic conditions it is theoretically possible to hydrolytically dechlorinate and defluorinate the partly halogenated H-CFCs: R21, R22, R32, R31 and R41, which form by reductive dehalogenation (Müller \& Lingens 1988; Hardman 1991). Furthermore, R32, R31 and R41 may be dechlorinated and defluorinated oxidatively with the help of an enzyme, the monooxygenase. This biodegradation method probably can also occur cometabolically (Cook et al. 1987; DeFlaun et al. 1992). The halogenated methanols which form during the hydrolytic dehalogenation process are unstable under aerobic conditions, a halogen can separate and, together with a hydrogen atom, the methanols can transform into a (halogenated) aldehyde. This aldehyde is oxidized with the help of a dehydrogenase into a (halogenated) carboxylic acid which can be degraded into carbon dioxide or methane, depending on the environmental conditions. Due to a lower binding energy, the splitting up of chlorine takes place before that of fluorine. Theoretically, there may also occur an oxidative dehalogenation of the halogenated methanol with a dihydroxymethane being formed. The theoretical hydrolytical dehalogenation of R22, R21 and R31 is given in Table 1 .

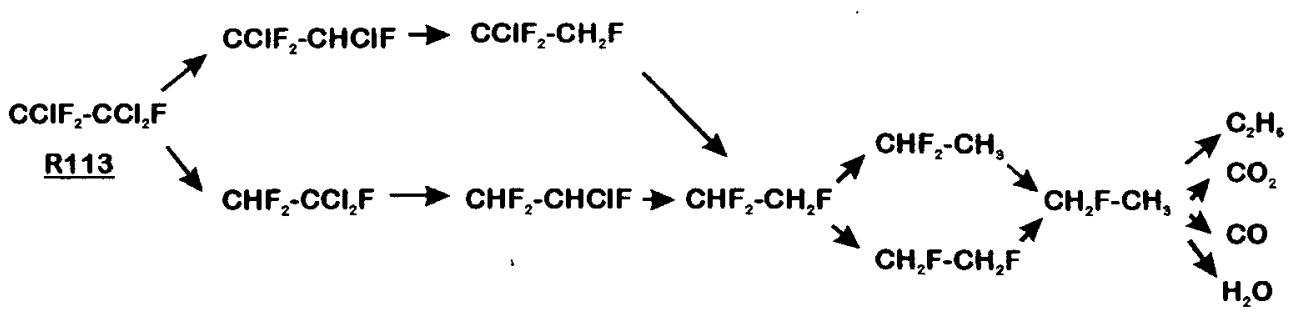

Fig. 1. Theoretical reductive dechlorination and defluorination of 1, 1,2-trichlorotrifluoroethane (R 113 ). 


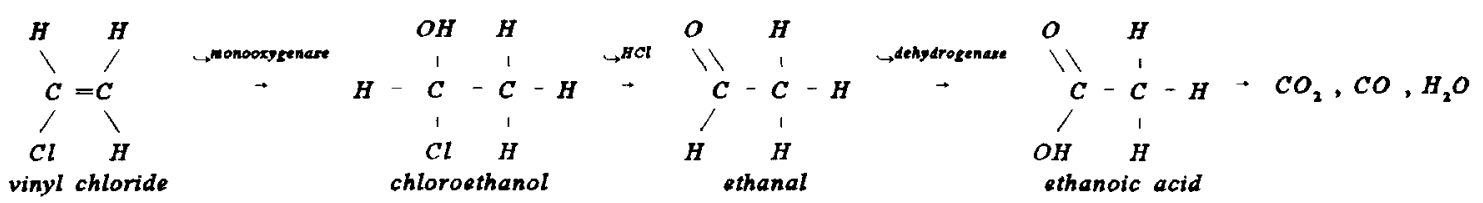

Fig. 2. Theoretical oxidative dechlorination of vinyl chloride.

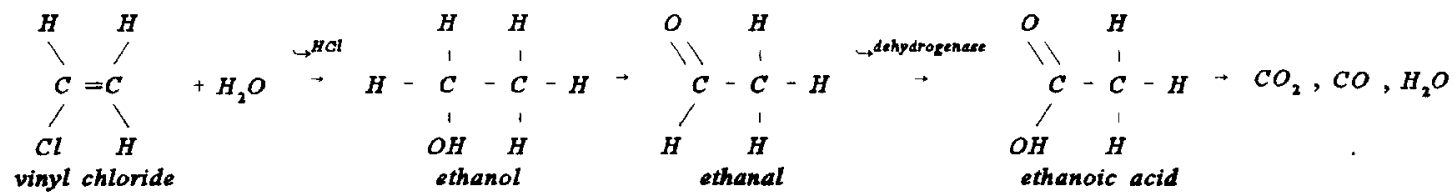

Fig. 3. Theoretical hydrolytic dechlorination of vinyl chloride.

The aerobic biodegradation of vinyl chloride to carbon dioxide has been described in the literature (e.g. Hartmans et al. 1985; Vogel \& McCarty 1987). The oxidative dechlorination of vinyl chloride could take place as shown in Fig. 2.

Hydrolytic dechlorination under anaerobic conditions would also be a possible degradation path (Fig. 3).

The actual degradation path is not generally known. The possibility of biological decomposition of vinyl chloride in marl (under aerobic conditions) and in compost (under anaerobic conditions) was investigated.
Biodegradation of CFCs, VC and R32 under anaerobic conditions

Materials and methods

In the experiments, 3-liter glass digesters (Fig. 4) were filled with $1.6 \mathrm{~kg}$ of mature sieved compost. The compost was made from organic waste collected from private households in Hamburg (Germany). The biological processes in the compost had largely come to an end so that only a relatively low gas production was expected.

\section{glass digester} $\left(80 \mathrm{~cm}^{2} \times 40 \mathrm{~cm}\right.$ )

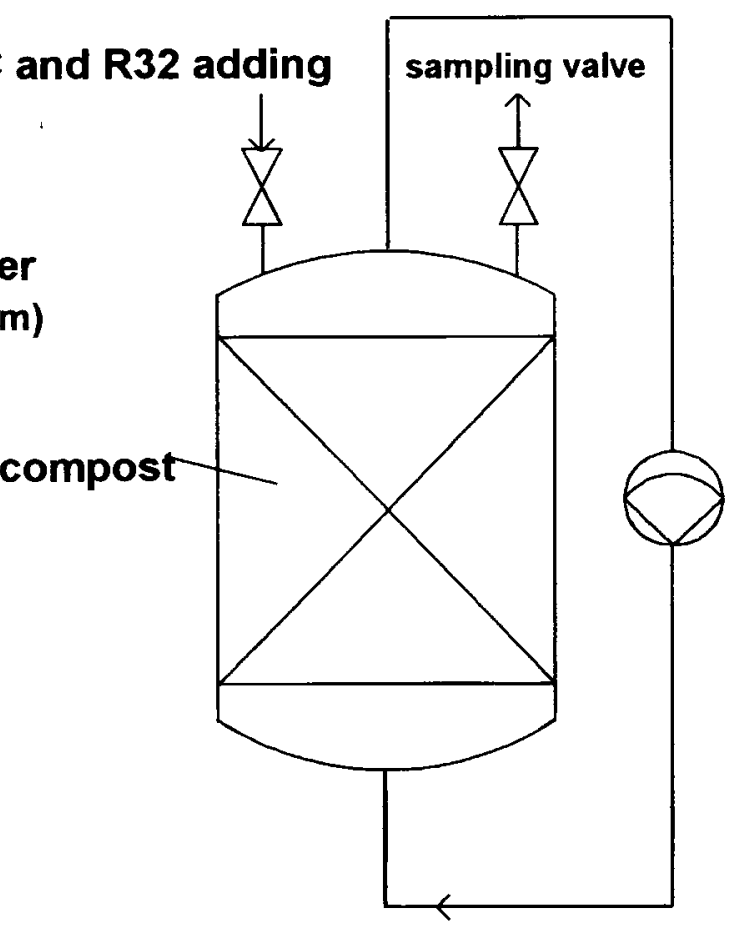

gas circulation

\section{pump (0.6 $\left.\mathrm{I}_{\text {gas }} / \mathrm{min}.\right)$}


Table 2. Test parameters for the 3-liter glass digesters filled with compost.

\begin{tabular}{lrr}
\hline Glass digester & \multicolumn{1}{c}{1} & \multicolumn{1}{c}{2} \\
\hline Built-in mass of compost [gwM] & 1600 & 1600 \\
Water content of compost $[\% \mathrm{WM}]$ & 50 & 50 \\
Built-in density $\left[\mathrm{kg}_{\mathrm{wm}} / \mathrm{l}\right]$ & 0.737 & 0.743 \\
Built-in volume $\left[\mathrm{m}^{3}\right]$ & $2.16 \times 10^{-3}$ & $2.2 \times 10^{-3}$ \\
Components added & $\mathrm{VC}(1.4 \mathrm{mg})$ & $\mathrm{R} 11(3 \mathrm{mg})$ \\
& $\mathrm{R} 113(3.2 \mathrm{mg})$ & $\mathrm{R} 12(2.5 \mathrm{mg})$ \\
& $\mathrm{R} 32(2.4 \mathrm{mg})$ & \\
& $\mathrm{R} 12(2.5 \mathrm{mg})$ & \\
\hline
\end{tabular}

WM: wet mass

VC: vinyl chloride

R1 13: 1, 1,2-trichlorotrifluoroethane

R32: difluoromethane

R12: dichlorodifluoromethane

The gas phase was pumped continuously (at approximately $0.6 \mathrm{l}_{\mathrm{ga}} / \mathrm{min}$.) through the substrate, in cycles from the bottom to the top of the digesters, by means of a tube connected to the top and bottom of the digester and interconnected to a pump. A glass valve with a septum connected to the top of the digester was used to take gas samples and to add the CFCs, VC and R32.

The methane concentrations in all of the experiments ranged between 10 and 20 vol\%, whereas the carbon dioxide concentrations were approximately $30 \mathrm{vol} \%$ in the gas phase. All digesters received a maximum of $3 \mathrm{mg}$ of substrate per $\mathrm{kg}$ dry mass of CFCs, VC and R32. The maximum concentration was set such that competitive inhibition of the biological process was avoided. Available data in the literature indicate that the minimum concentration of halogenated methane analogues at which level an inhibition of methane production can be clearly seen at approximately $10 \mathrm{mg}$ per $\mathrm{kg}$ dry mass (Poller 1990). The test parameters are shown in Table 2.

\section{Analyses}

The halogenated trace substances and their metabolites in the gas phase of the test digesters were examined with standard analytical methods by means of gas chromatography. In order to control the environmental conditions, the gas composition (methane; carbon dioxide; hydrogen; oxygen; nitrogen) was also analyzed by means of gas chromatography.

The same analytical methods were used for the experiments described in the section titled H-CFCs and VC biodegradation under aerobic conditions.

\section{Results}

In the experiments carried out in the laboratory under idealized conditions (room temperature $30^{\circ} \mathrm{C}$ and material moisture content $>50 \%$ ) all the halogenated decomposition products could be determined with the exception for analytical reasons of R41, R32 and the decomposition products of R113, because of insufficient selectivity of the used analytical gas chromatography columns (non-ventilated experimental systems: $50 \mathrm{~m} \times 0.53 \mathrm{~mm}$ PLOT capillary column

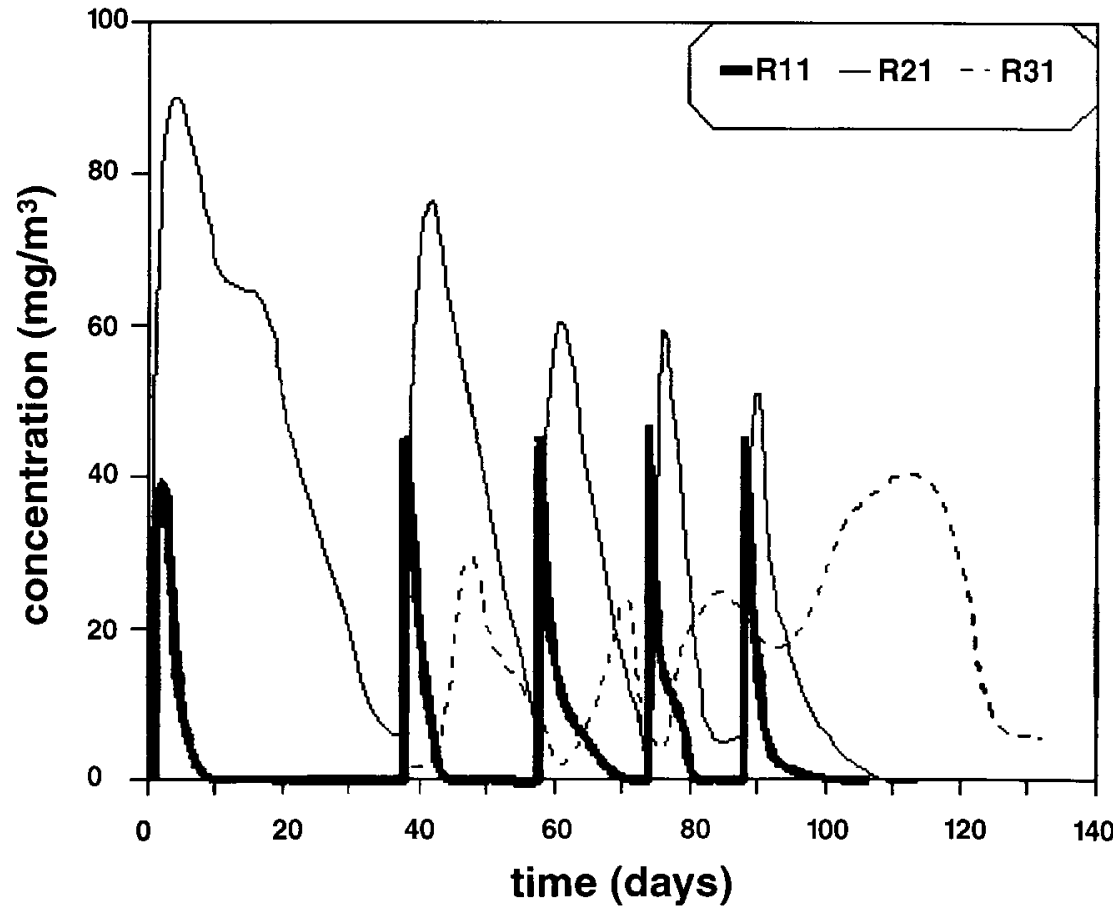

Fig. 5. Concentration diagrams of R11, R21 and R3 1 in the gas phase of 3-liter test digester number 2 filled with compost. 


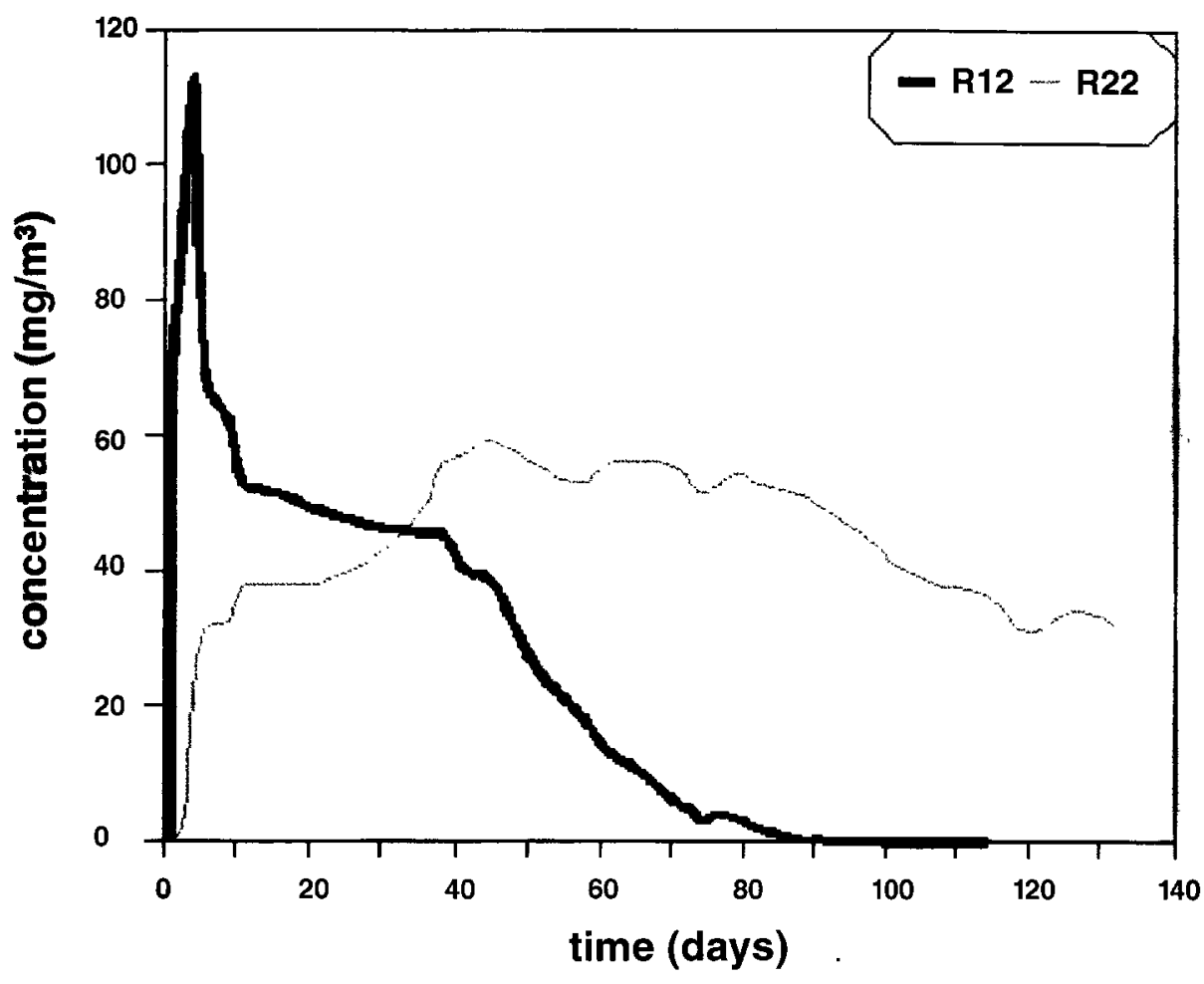

Fig. 6. Concentration diagrams of $R 12$ and R22 in the gas phase of 3-liter test digester number 2 filled with compost.

$\left(\mathrm{Al}_{2} \mathrm{O}_{3} / \mathrm{KCl}\right.$, film thickness $\left.10 \mu \mathrm{m}\right)$ and ventilated experimental systems: $50 \mathrm{~m} \times 0.53 \mathrm{~mm}$ Fused Silica WCOT capillary column (CP-Sil 5; film thickness $5 \mu \mathrm{m}$ ), Chrompack 1992).

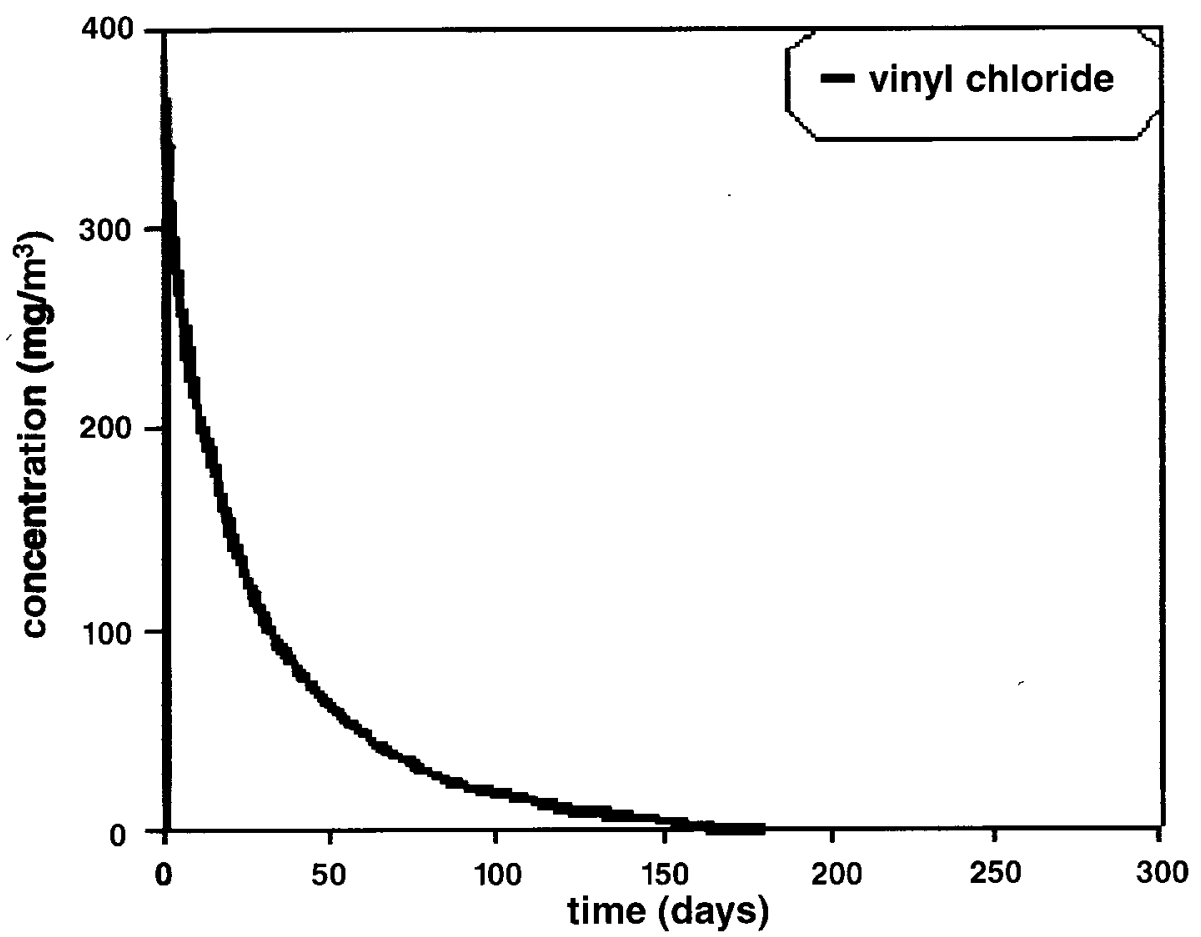

During the first 140 days of the test period, $3 \mathrm{mg}$ of $\mathrm{R} 11$ were added five times and $2.5 \mathrm{mg}$ of R12 were added once. Only a few hours after the addition of R11 substantially higher concentrations of R21 than of R11 could be measured,
Fig. 7. Concentration diagram of vinyl chloride in the gas phase of 3 -liter test digester number 1 filled with compost. 


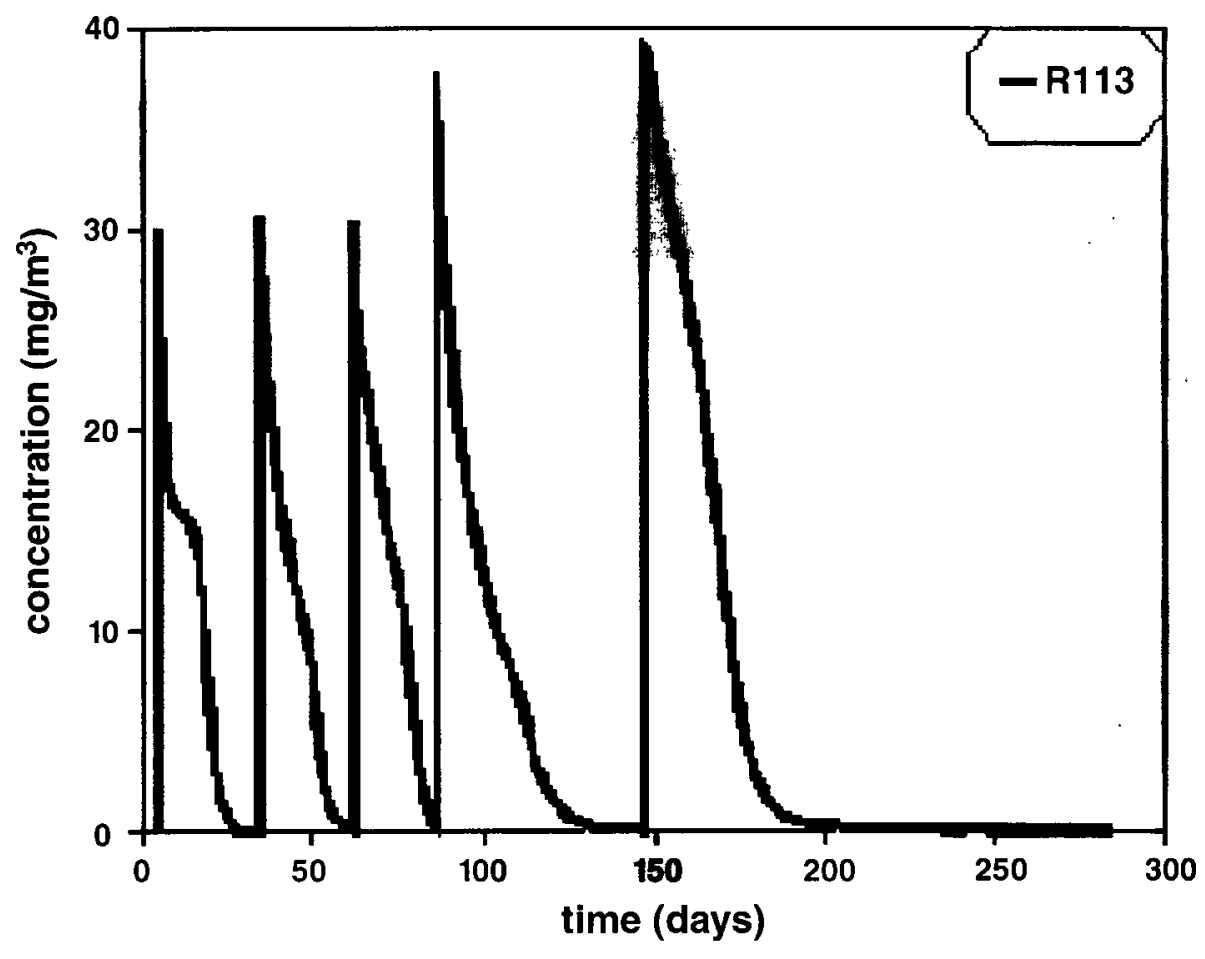

Fig. 8. Concentration diagram of R 113 in the gas phase of 3-liter test digester number 1

filled with compost.

which was presumably due to the adsorption of R11 at the moist material. The curves in Fig. 5 show the concentrations of R11 and of R31 in the digester.

The R21, reduced by microorganisms from R11, was further degraded within 40 days after the first addition. At that

point the biodegradation product of R21 (R31) could be detected, whose concentration first increased and then decreased as well, but in a longer degradation time than R21. Hence, it must be assumed that $\mathrm{R} 31$ had been decomposed as well. Because of the distinctly declining degradation time of

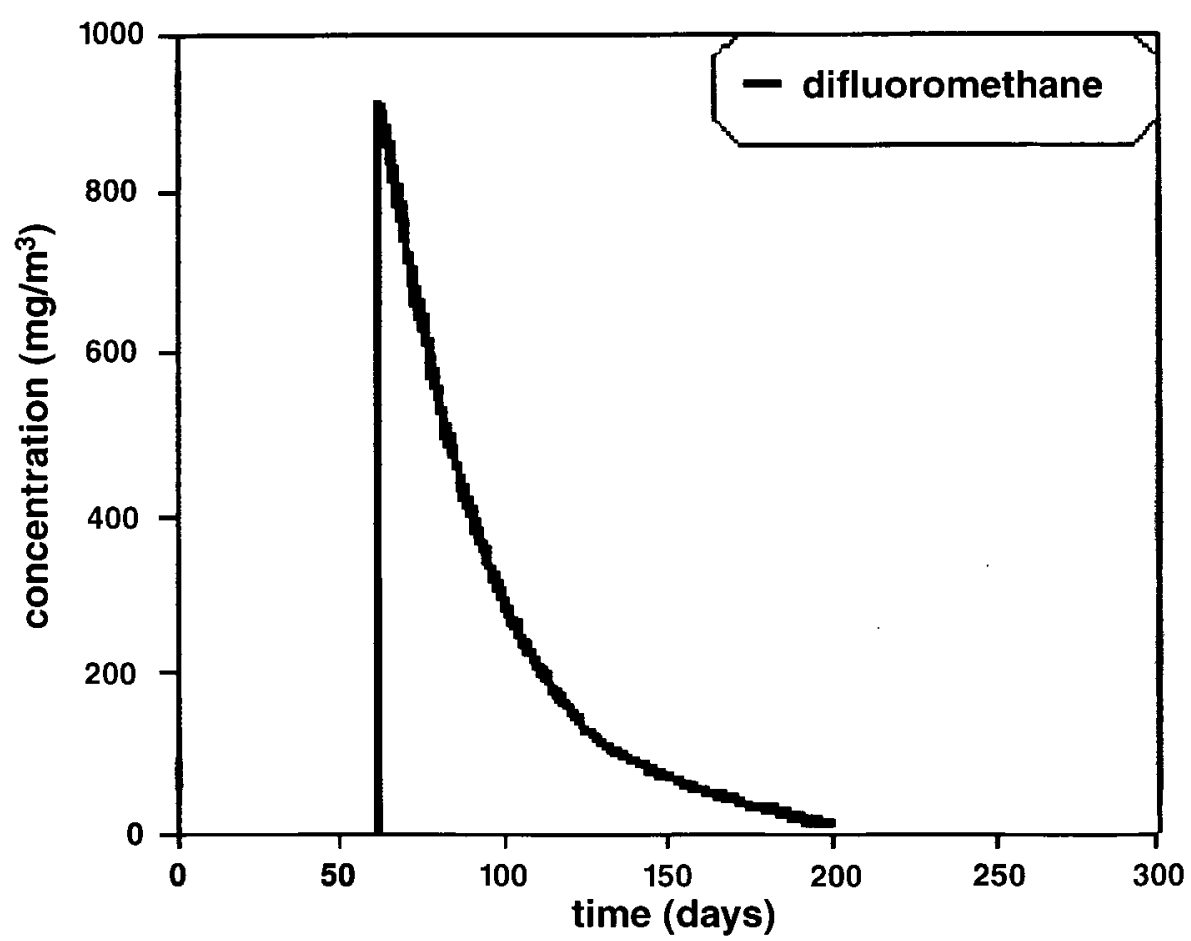

Fig. 9. Concentration diagram of difluoromethane in the gas phase of 3-liter test digester number 1 filled with compost. 
Table 3. Average degradation rates of CFCs, vinyl chloride and difluoromethane in 3-liter test digesters under anaerobic test conditions.

\begin{tabular}{|c|c|c|c|c|c|}
\hline $\begin{array}{c}\text { Glass digester } \\
\text { (filled with compost) }\end{array}$ & $\begin{array}{c}\text { Simulated conditions } \\
\text { of landfill }\end{array}$ & Components added & $\begin{array}{l}\text { Max. gas concentrations } \\
\qquad\left(\mathrm{mg} / \mathrm{m}^{3}{ }_{\text {gos }}\right)\end{array}$ & $\begin{array}{l}\text { Products of } \\
\text { degradation }\end{array}$ & $\begin{array}{l}\text { Average values of degradation rate } \\
\qquad\left(\mathrm{mg} / \mathrm{m}^{3}{ }_{\text {mat vol }} / \mathrm{h}\right)\end{array}$ \\
\hline \multirow[t]{4}{*}{1} & Stable methanephase & $\mathrm{R} 12$ & 117.3 & R22 & $\sim 1$ \\
\hline & & R113 & 39.1 & (?) & 1.2 \\
\hline & & Vinyl chloride & 364.7 & $\mathrm{CO}_{2}(?), \mathrm{H}_{2} \mathrm{O}$ & 0.2 \\
\hline & & Difluoromethane & 912.0 & $\begin{array}{c}(?) \\
\text { R4l(?) }\end{array}$ & 0.3 \\
\hline 2 & & & & $\mathrm{R} 22$ & \\
\hline
\end{tabular}

R12: dichlorodifluoromethane; R 1 13: 1,1,2-trichlorotrifluoroethane;

R1 1: trichlorofluoromethane; R22: chlorodifluoromethane; R21: dichlorofluoromethane

R3 1: chlorofluoromethane; R41: fluoromethane

R21 it is supposed that adaptation of the microorganisms degrading R21 had taken place.

Under anaerobic conditions, R12 is not as easily biodegradable as R11. The resulting metabolite, R22, either was not decomposed or decomposed slowly. The results are shown in Fig. 6.

Adaptation of the bacteria that probably are responsible for the biodegradation of the fully halogenated CFCs under anaerobic conditions (methanogenic and acetogenic bacteria) did not occur.
The concentration diagrams of the substances VC, R113 and R32 in digester number 1 can be seen in Figs. 7 to 9 .

The results of the tests show that R12 was degraded twice as fast in this experiment as in the tests where R11 had also been added. This is probably due to the absence of R11 and its biodegradation products, since they have inhibiting effects.

Vinyl chloride was dehalogenated at a low degradation rate under anaerobic conditions (Vogel \& McCarty 1985; Freedman \& Gossett 1989). Difluoromethane was also degraded slowly.

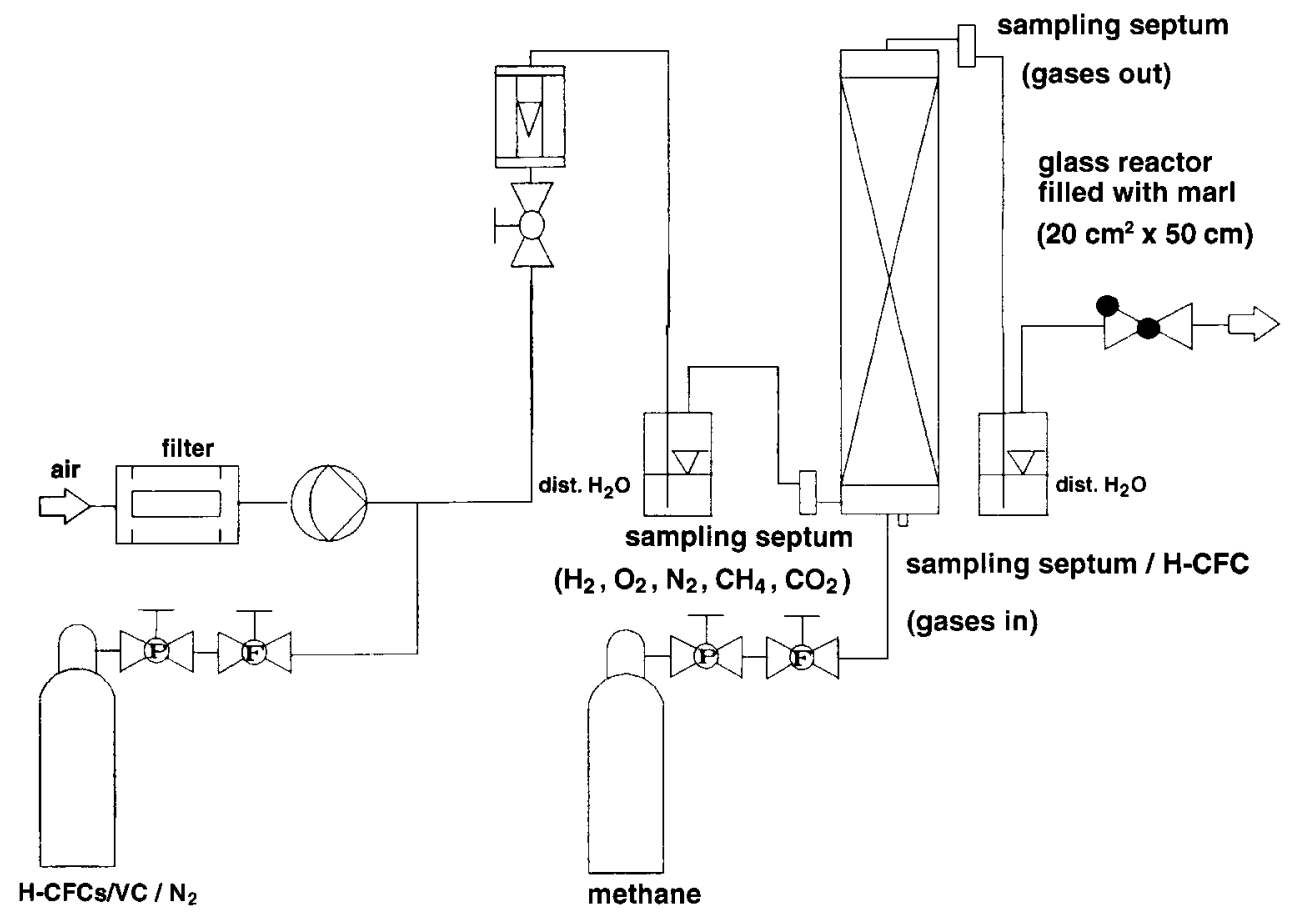

Fig. 10. Scheme of the continuous aerobic microbiological degradation of $\mathrm{H}-\mathrm{CFC} / \mathrm{VC}$ in 1 -liter reactors. 
a)

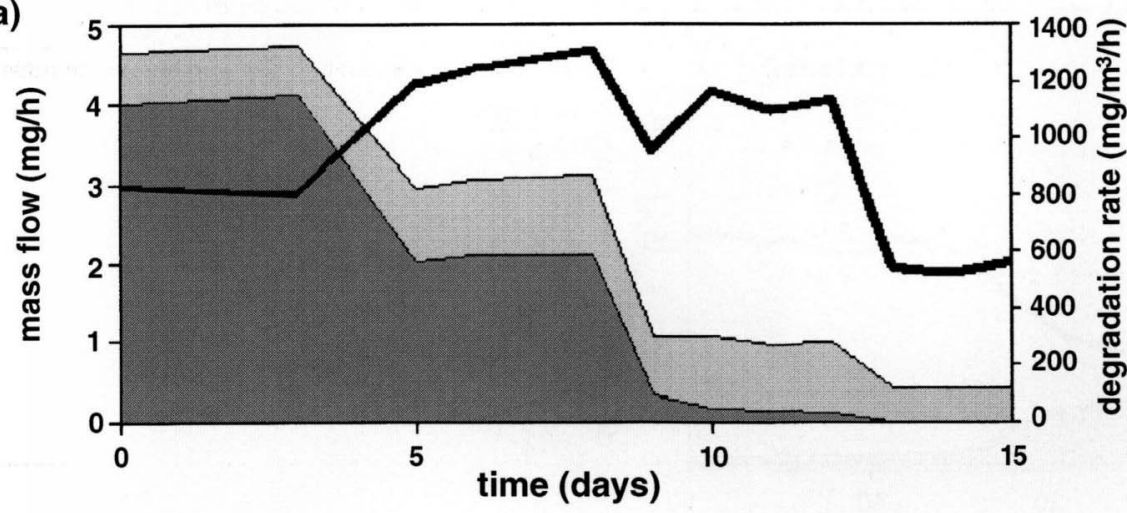

VC degradation rate VC outnut
Fig. 11. Degradation of: a) vinyl chloride; and b) methane under aerobic conditions by methanotrophic bacteria (reactor number 1). b)

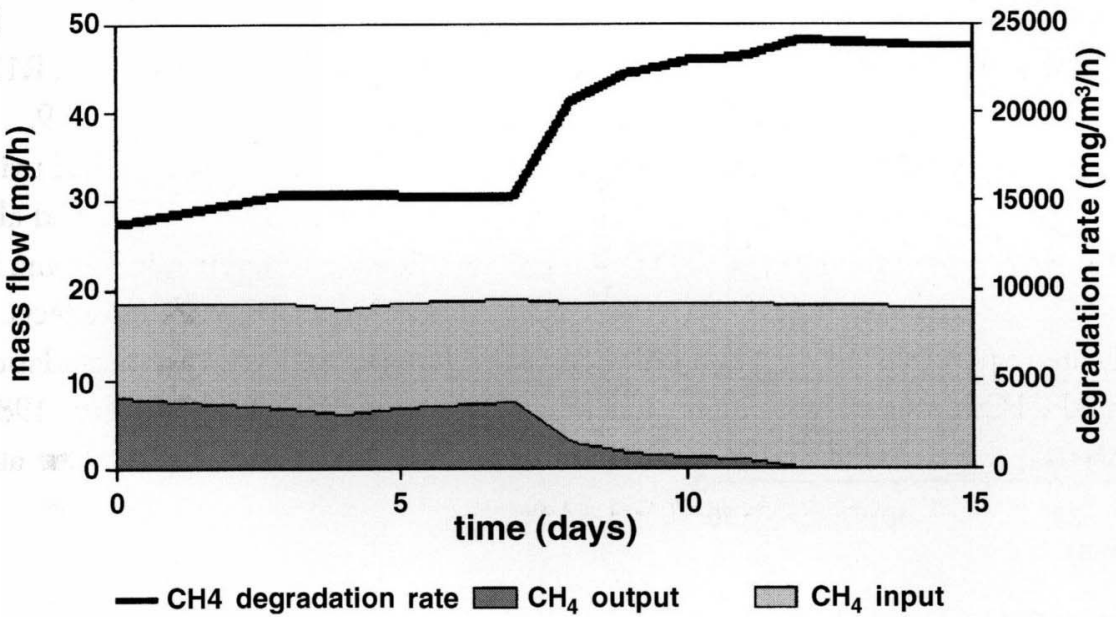

To ensure a comparability of the results, the degradation rates were determined as follows:

$$
r=\frac{m}{V \cdot t_{h}}
$$

$\begin{array}{lll}\text { degradation rate } & r & {\left[\mathrm{mg} / \mathrm{m}^{3}{ }_{\text {mat. }} / \mathrm{h}\right]} \\ \text { mass of CFCs/VC adding } & m & {[\mathrm{mg}]} \\ \text { material volume } & V & {\left[\mathrm{~m}^{3}\right]} \\ \text { degradation time } & t_{h} & {[\mathrm{~h}]}\end{array}$

It can be shown that $\mathrm{R} 11$ was degraded in all digesters with an average degradation rate of approximately $7 \mathrm{mg} / \mathrm{m}^{3} \mathrm{co} / \mathrm{h}$; leading to the biodegradation products R21 and R31. The compound R12 was decomposed as well; but at a considerably lower degradation rate (approximately 0.5 to $1 \mathrm{mg} / \mathrm{m}^{3} \mathrm{co} / \mathrm{h}$ ). The compound R22 occured as biodegradation product of R12, which is not likely to be decomposed under anaerobic conditions. The degradation rates of vinyl chloride and difluoromethane were low at $0.2 \mathrm{mg} / \mathrm{m}^{3}{ }_{\text {co. }} / \mathrm{h}$ and at $0.3 \mathrm{mg} / \mathrm{m}^{3}{ }_{\text {co }} / \mathrm{h}$, respectively. R113 ranked second after R11 with a degradation rate of $1.2 \mathrm{mg} / \mathrm{m}_{\mathrm{co}}^{3} / \mathrm{h}$. The results have been summarized in Table 3 .

Table 4. Test parameters of the 1-liter reactors filled with marl.

\begin{tabular}{lrr}
\hline Reactor & \multicolumn{1}{c}{1} & \multicolumn{1}{c}{2} \\
\hline Built-in mass of marl [gwm] & 1000 & 1000 \\
Built-in mass of adapted marl [g $\mathrm{wm}$ ] & 100 & 100 \\
Water content of marl [\%WM] & 8.86 & 8.86 \\
Water content of adapted marl [\%WM] & 4.43 & 4.43 \\
Density of wet mass [kgWM/l] & 1.448 & 1.357 \\
Built-in volume [m ${ }^{3}$ ] & $0.760 \times 10^{-3}$ & $0.811 \times 10^{-3}$ \\
Components (continuously added) & $\mathrm{VC}$ & $\mathrm{R} 21, \mathrm{R} 22$ \\
Methane concentration [vol\%] & 3 & 2 \\
Gas flow [ml/min.] & 15 & 15 \\
\hline
\end{tabular}

WM: wet mass

R21: dichlorofluoromethane

R22: chlorodifluoromethane

VC: vinyl chloride 
a)

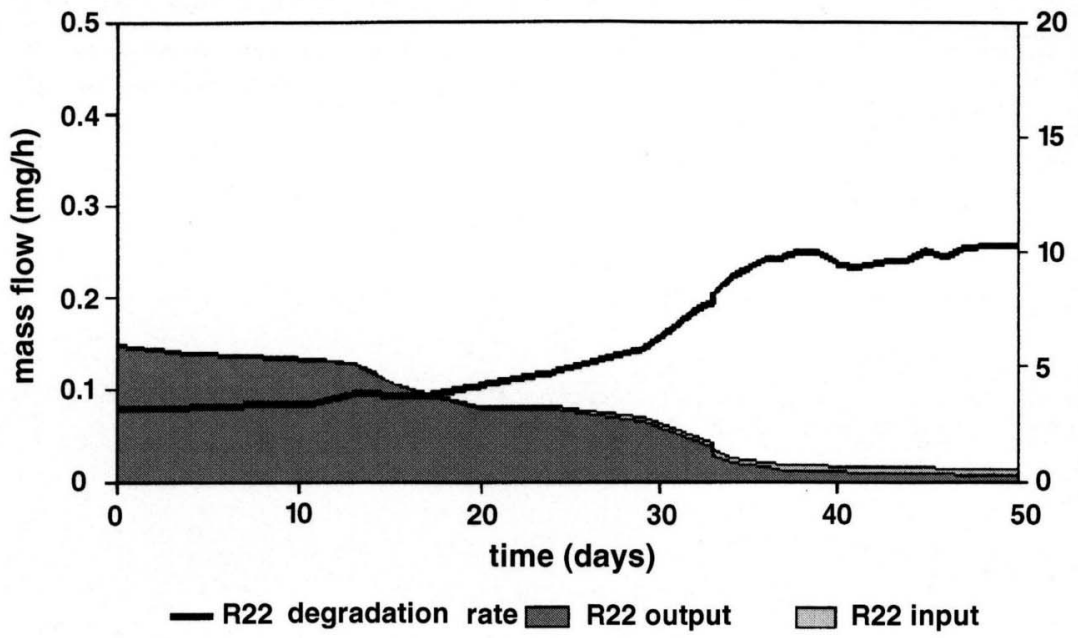

Fig. 12. Degradation of: a) R22; and b) methane under aerobic conditions by methanotrophic bacteria (reactor number 2). b)

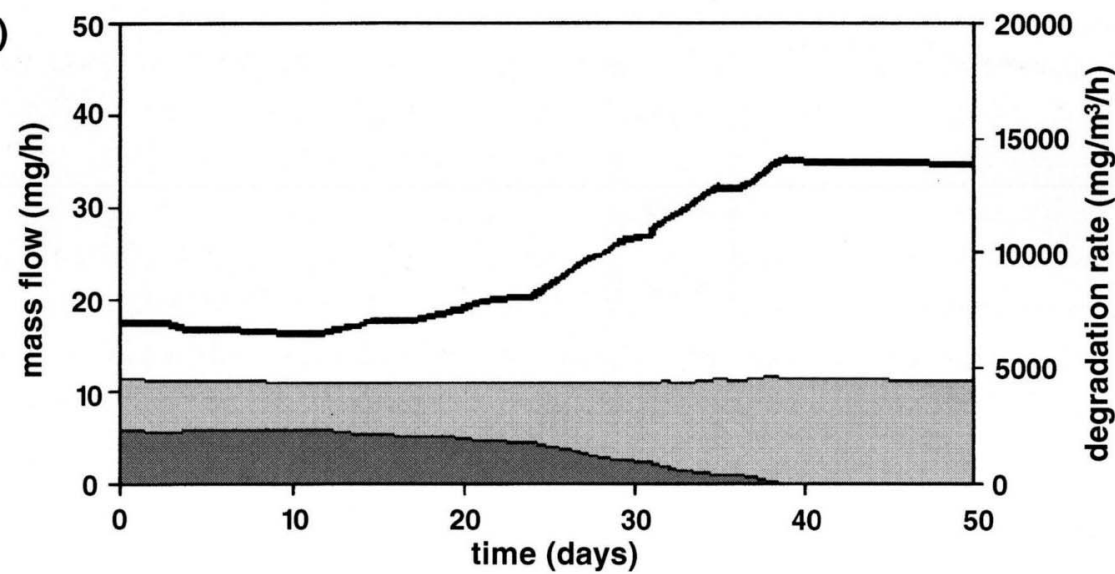

- $\mathrm{CH} 4$ degradation rate $\square \mathrm{CH}_{4}$ output $\square \mathrm{CH}_{4}$ input

\section{H-CFCs and VC biodegradation under aerobic conditions}

Materials and methods

In the aerobic experiments carried out in the laboratory under idealized conditions and with the introduction of methane a biodegradation of the partly chlorofluorinated hydrocarbons R22, R21 and VC (probably by methanotrophic bacteria (Fogel et al. 1986; Hanson et al. 1990; Chang \& Criddle 1995)) were investigated in marl (Deipser \& Stegmann 1997b).

In the experiments, 1-liter reactors were filled with marl (Fig. 10).

The air flow rate was fixed at $15 \mathrm{ml}$ per minute with a methane concentration of 2 and $3 \mathrm{vol} \%$, respectively. The concentration of $\mathrm{H}$-CFCs was between 10 and $200 \mathrm{mg} / \mathrm{m}^{3}$ gas in the gas phase of the reactors. The test parameters are shown in Table 4.
The retention times were calculated as follows:

$$
t_{r}=\frac{V}{\dot{V}}
$$

retention time

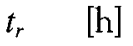

material volume

$V \quad\left[\mathrm{~m}^{3}\right]$

gas volume flow rate $\dot{V} \quad\left[\mathrm{~m}_{\text {gas }}^{3} / \mathrm{h}\right]$

The degradation rates were calculated on the basis of the mass inflow and outflow rates and the material volume as follows:

$$
r=\left(\dot{m}_{\mathrm{i}}-\dot{m}_{\mathrm{o}}\right) \cdot \frac{1}{V}
$$

$\begin{array}{lll}\text { degradation rate } & r & {\left[\mathrm{mg} / \mathrm{m}^{3} \text { mat } / \mathrm{h}\right]} \\ \text { mass inflow rate } & \dot{m}_{\mathrm{i}} & {[\mathrm{mg} / \mathrm{h}]} \\ \text { mass outflow rate } & \dot{m}_{\mathrm{o}} & {[\mathrm{mg} / \mathrm{h}]} \\ \text { material volume } & V & {\left[\mathrm{~m}^{3}\right]}\end{array}$




\section{Results}

The maximum degradation rate of vinyl chloride was $1300 \mathrm{mg} / \mathrm{m}_{\mathrm{ma}}^{3} / \mathrm{h}\left(V_{\mathrm{ma} .}=0.760 \times 10^{-3} \mathrm{~m}^{3}\right)$ as an input mass flow rate of $3 \mathrm{mg} / \mathrm{h}$. As an input mass flow rate of $0.5 \mathrm{mg} / \mathrm{h}$ and a gas concentration of $550 \mathrm{mg} / \mathrm{m}_{\text {gas }}^{3}\left(t_{\mathrm{r}}=51 \mathrm{~min}\right.$. $)$ methane would be degraded completely first. Before this value, methane biodegradation was inhibited (Fig. 11). The degradation rate of R21 could not be determined.

The maximum degradation rate of $\mathrm{R} 22$ was $10 \mathrm{mg} / \mathrm{m}^{3}{ }_{\mathrm{ma}} / \mathrm{h}$ $\left(V_{\text {ma. }}=0.811 \times 10^{-3} \mathrm{~m}^{3}\right)$ as an input mass flow rate of $0.015 \mathrm{mg} / \mathrm{h}$ and a gas concentration of $17.3 \mathrm{mg} / \mathrm{m}^{3}$ gas. At this concentration methane would be completely degraded first. At higher concentrations of $\mathrm{R} 22$ the methane biodegradation was competitively inhibited (Fig. 12).

The experiments showed that the degradation rate depends on the presence of methanotrophic bacteria. The nutrient supply seems to be less important, as experiments with nutrient-poor marl have shown (see also Witt 1991). It is assumed that the biodegradation occurs in form of a hydrolytic and oxidative dehalogenation which takes place in cometabolism. So the H-CFCs can probably be dehalogenated hydrolytically (cometabolically) under aerobic and anaerobic conditions. Under both conditions degradation rates were relatively low (only some $\mathrm{mg} / \mathrm{m}^{3}{ }_{\text {ma }} / \mathrm{h}$; Table 5 ).

\section{Significance of the results on conventional reactor landfills}

Under anaerobic conditions, typical of conventional reactor landfills with activity of methanogenic bacteria, the concentrations of volatile fully halogenated CFCs will decrease with time. As a result partly halogenated hydrocarbons can occur. In defiance of active or passive LFG collection, permanent gases and trace substances can reach the mineral layer of landfill surfaces.
On the basis of the results of the tests the concentration of vinyl chloride will be reduced significantly when the gas leaves the surface of landfills. For example, if LFG with 3 vol\% methane penetrate a $39 \mathrm{~cm}$ nutrient-poor mineral landfill covering (e.g. marl with circa $9 \%_{\text {wer mass }}$ water content) with $15 \mathrm{ml}$ per minute - a realistic value for landfill surfaces (Figueroa \& Stegmann 1991) - $550 \mathrm{mg} / \mathrm{m}^{3}$ gas vinyl chloride (approximately twice the maximum quantity of measured LFG concentration in Germany (Poller 1990)) could be degraded. At this concentrations of methanotrophic bacteria; methane degradation would not be reduced significantly.

The partly halogenated $\mathrm{H}$-CFCs with a small quantity of halogen atoms in the molecule and from it the H-CFCs with a lower quantity of fluoroatoms were degraded with priority under aerobic conditions.

R21 could be degraded at a concentration lower than $19 \mathrm{mg} / \mathrm{m}_{\text {gas }}^{3}$ (maximum concentration measured in LFG was $14 \mathrm{mg} / \mathrm{m}^{3}$ gas in Germany). For this, the area loading of R21 must be lower than $35 \mathrm{mg} / \mathrm{m}^{2} / \mathrm{h}$.

At a methane concentration of $2 \mathrm{vol} \%$, a $36 \mathrm{~cm}$ high marl layer and a R22 concentration of $30 \mathrm{mg} / \mathrm{m}^{3}$ gas (near the maximum concentration of R22 measured in LFG in Germany), the R22 could be degraded about $38 \%$. The methane oxidation would not be inhibited at a concentration lower than $17.3 \mathrm{mg} / \mathrm{m}_{\text {gas }}^{3}$.

The values of the examples are valid for the experimental conditions and only partly valid for actual landfill surface conditions. Essentially, the volatile trace substance composition, methane and oxygen concentration, physical conditions (like temperature; water content; porosity; void spaces; grain size distribution, etc.) and kinetic parameters (like gas flow rate and speed; gas distribution and area loading of substance, etc.) affect the biodegradation.

Table 5. Degradation rates of vinyl chloride and H-CFCs in 1-liter reactors under aerobic conditions.

\begin{tabular}{|c|c|c|c|c|c|c|c|c|c|}
\hline $\begin{array}{l}\text { reactor } \\
\text { (filled with marl) }\end{array}$ & $\begin{array}{l}\text { H-CFCs/ } \\
\text { VC added }\end{array}$ & $\begin{array}{c}\text { max. degradation } \\
\text { rate } \\
\left.\left(\mathrm{mg} / \mathrm{m}^{3}{ }_{\mathrm{m}} / \mathrm{h}\right)\right)\end{array}$ & $\begin{array}{c}\text { max. degradation } \\
\text { rate } \\
(\%)\end{array}$ & $\begin{array}{c}\text { input } \\
\left(\mathrm{mg} / \mathrm{m}^{3}{ }_{\text {gos }}\right)\end{array}$ & $\begin{array}{c}\text { retention time } \\
\text { (min.) }\end{array}$ & $\begin{array}{l}\mathrm{CH}_{4} \\
\text { (v.\%) }\end{array}$ & $\mathrm{CH}_{4}$-inhibit. & $\begin{array}{c}\mathrm{CH}_{4} \text {-degradation } \\
\text { rate } \\
\left(\mathrm{g} / \mathrm{m}_{\mathrm{gcs}}^{3} / \mathrm{h}\right)\end{array}$ & $\begin{array}{l}\text { subst. area } \\
\text { loading } \\
\left(\mathrm{mg} / \mathrm{m}^{2}{ }_{\mathrm{m}} / \mathrm{h}\right)\end{array}$ \\
\hline 1 & VC & 1300 & $>99$ & 550 & 51 & 3 & $\begin{array}{c}\text { yes } \\
(<50 \%)\end{array}$ & 24 & 2300 \\
\hline 2 & R22 & 10 & 41 & 17.3 & 54 & 2 & yes & 14 & 80 \\
\hline & R21 & n.m. & n.m. & 19.5 & & & $\begin{array}{c}\text { yes } \\
(\Sigma<50 \%)\end{array}$ & & $<35$ \\
\hline
\end{tabular}

n.m.: not measurable

VC: vinyl chloride

R21: dichlorofluoromethane

R22: chlorodifluoromethane 


\section{Summary and conclusions}

The experiments have shown that the volatile fully halogenated CFCs R11, R12 and R113, which for a long time have been considered non-biodegradable, and R21, R31, R32 and $\mathrm{VC}$ can be microbiologically decomposed under methanogenic anaerobic conditions. The theoretical biodegradation paths of fully halogenated CFCs and of partly halogenated $\mathrm{H}$ CFCs and VC were partly confirmed by the investigations carried out in compost and marl.

Theoretically, depending on their molecular structure, the partly halogenated H-CFCs and VC can be degraded hydrolytically under aerobic and anaerobic conditions or oxidatively under aerobic conditions. The investigations have shown that under aerobic conditions VC was degraded in relatively high concentrations in marl. The partly halogenated H-CFCs R22 and R21 were dehalogenated at a low degradation rate. Under aerobic conditions they have competitively inhibited the biodegradation of methane by methanotrophic bacteria (from a concentration higher than about 20 $\left.\mathrm{mg} / \mathrm{m}_{\text {gas }}^{3}\right)$.

The $\mathrm{CFC} / \mathrm{H}-\mathrm{CFC} / \mathrm{VC}$ concentrations in LFG will decrease with time because they can be removed with the LFG that is emitted or extracted from the landfill and, secondly, they can be partly or completely biologically degraded. But the reductions rates in the landfill will be lower than those calculated on the basis of the degradation rates in laboratory tests. This is, in particular, due to varying physical conditions in the landfills like temperature and humidity. When mining or reconstructing old landfills today it should thus be considered that there are still VCCs/CFCs and increasing concentrations of $\mathrm{H}-\mathrm{VCCs} / \mathrm{H}-\mathrm{CFCs}$, which might escape into the atmosphere.

\section{Acknowledgements}

This project was funded by the "Deutsche Forschungsgemeinschaft (DFG)".

\section{References}

Bouwer, E. J. \& McCarty, P. L. (1983) Transformation of 1- and 2-carbon halogenated aliphatic organic compounds under mcthanogenic conditions. Applied and Environmental Microbiology 45, 1286-1294.

Chang, W. \& Criddle, C. S. (1995) Biotransformation of HCFC-22; HCFC142b; HCFC-123; and HFC-134a by methanotrophic mixed culture MM1. Biodegradation 6, 1-9.

Christensen, T. H., Kjeldsen, P., Albrechtsen, H.-J., Heron, G., Nielsen, P. H., Bjerg, P. L. \& Holm, P. E. (1994) Attenuation of Landfill Leachate Pollutants in Aquifers. Evironmental Science and Technology 24 (2), 119-202.

Cook, A. M., Scholtz, R. \& Leisinger, T. (1987) Mikrobieller Abbau von halogenierten aliphatischen Verbindungen (Microbiological degradation of halogenated aliphatic compounds). 5. DECHEMAFachgespräch Umweltschutz. gwf Biotechnologie 128, 7-15.

DeFlaun, M. F., Ensley, B. D. \& Steffan, R. J. (1992) Biological oxidation of hydrochlorofluorocarbons (HCFCs) by a methanotrophic bacterium. Bio/Technology 10 (12), 1576-1578.

Deipser, A. \& Poller, T. (1990) Laborbestimmung von FCKW und LCKW im Hausmüll (Laboratory determination of CFCs and VCCs in MSW). Entsorgungs-Praxis 6, 373-375.

Deipser, A. \& Stegmann, R. (1993) Untersuchungen von Hausmüll auf leichtflüchtige Spurenstoffe, (Investigations on volatile trace substances in MSW). Müll und Abfall 2, 69-81.

Deipser, A. \& Stegmann, R. (1994) The Origin and Fate of Volatile Trace Components in Municipal Solid Waste Landfills. Waste Management $\mathscr{E}$ Research 12, 129-139.

Deipser, A., Poller, T. \& Stegmann, R. (1996) Emissions of Volatile Halogenated Hydrocarbons from Landfills. In: Christensen, T. H., Cossu, R. \& Stegmann, R. (eds.) Landfilling of Waste: Biogas. London, UK: E \& FN Spoon. pp. 59-72.

Deipser, A. \& Stegmann, R. (1997a) Biological degradation of VCCs and CFCs under simulated anaerobic landfill conditions in laboratory test digesters. Environmental Science and Pollution Research 4 (4), 209-216.
Deipser, A. \& Stegmann, R. (1997b) Deponiegas: Biologischer Abbau von teilhalogenierten H-FCKW und Vinylchlorid unter aeroben Bedingungen bei Anwesenheit von Methan. (Landfill gas: Biological degradation of partly halogenated H-CFCs and vinyl chloride under aerobic conditions in presence of methane.) Umweltwissenschaften und Schadstoff-Forschung 9 (6), 309-316.

Fathepure, B. Z. \& Boyd, S. A. (1988) Dependence of Tetrachloroethylene Dechlorination on Methanogenic Substrate Consumption by Methanosarcina sp. Strain DCM. Applied and Environmental Microbiology 54 (12), 2976-2980.

Figueroa, R. A. \& Stegmann, R. (1991) Gas Migration through Natural Liners. In: Christensen, T.H., Cossu, R. \& Stegmann, R. (eds) Proceedings Sardinia '91, Third International Landfill Symposium. Cagliari, Italy: CISA. pp. $167-177$.

Fogel, M. M., Taddeo, A. R. \& Fogel, S. (1986) Biodegradation of Chlorinated Ethenes by a Methane-Utilizing Mixed Culture. Applied and Environmental Microbiology 51 (4), 720-724.

Freedman, D. L. \& Gossett, J. M. (1989) Biological Reductive Dechlorination of Tetrachloroethylene and Trichloroethylene to Ethylene under Methanogenic Conditions. Applied and Environmental Microbiology 55 (9), 2144-2151.

Hanson, R. S., Tsien, H. C., Tsuji, K., Brusseau, G. A. \& Wackett, L. P. (1990) Biodegradation of low-molecular-weight halogenated hydrocarbons by methanotrophic bacteria. FEMS Microbiology Reviews 87, 273-278.

Hardman, D. J. (1991) Biotransformation of Halogenated Compounds. Critical Reviews in Biotechnology 11 (1), 1-40.

Hartmans, S., De Bont, J. A. M., Tramper, J. \& Luyben, K. Ch. A. M. (1985) Bacterial Degradation of Vinyl Chloride. Biotechnology Letters 7 (6), 383-388.

Krone, U. E., Thauer, K., Hogenkamp, H. P. C. \& Steinbach, K. (1991) Reductive Formation of Carbon Monoxide from $\mathrm{CCl}_{4}$ and $\mathrm{FREONs} 11$; 12; and 13 Catalyzed by Corrinoids. Biochemistry 30, 2713-2719. 
Lesage, S., Brown, S. \& Hosler, K. R. (1992) Degradation of chlorofluorocarbon- 113 under anaerobic conditions. Chemosphere 24 (9), 1225-1243.

Müller, R. \& Lingens, F. (1988) Der mikrobielle Abbau von chlorierten Kohlenwasserstoffen (The microbiological degradation of chlorinated hydrocarbons). gwf Biotechnologie 129, 55-60.

Poller, T. (1990) Hausmülbürtige LCKW/FCKW und deren Wirkung auf die Methangasbildung (VCCs/CFCs from domestic wastes and their function of the methane gas production). Bonn, Germany: Economics Verlag.

Vogel, T. M., Criddle, C. S. \& McCarty, P. L. (1987) Transformations of halogenated aliphatic compounds. Environmental Science and Technology $21,722-736$.
Vogel, T. M. \& McCarty, P. L. (1985) Biotransformation of tetrachloroethylene to trichloroethylene; dichloroethylene; vinyl chloride; and carbon dioxide under methanogenic conditions. Applied and Environmental Microbiology 5, 1080-1083.

Vogel, T. M. \& McCarty, P. L. (1987) Abiotic and Biotic Transformatıons of 1;1;1-Trichloroethane under Methanogenic Conditions. Environmental Science and Technology 21 (112), 1208-1213.

Witt, D. (1991) Mikrobieller Abbau von Kohlenwasserstoffen und Kohlenwasserstoffverbindungen (Microbiological degradation of hydrocarbons and combinations of hydrocarbons). DGMKForschungsbericht 461-01. Hamburg, Germany: DGMK Deutsche Wissenschaftliche Gesellschaft für Erdöl, Erdgas und Kohle e. V. 